-776一 九 州崡会 誌 · 第 24 巻第 6 号 (1971)

\title{
数種の硬組織疾患歯特に豴歯の分裂線について
}

九州茵科大学解剖学教室（指導：中山種秋教授）

村上守良

（昭和46年 1 月20日受理）

（本論文の要旨は昭和42年10月第 9 回歯科基礎医学会総会, 昭和42年11月第27回九州䨑科学会総会, 昭和 43 年 4 月第73回日本解剖学会総会に扎いて発表した）

\section{A STUDY ON THE SPLITTING LINES IN A FEW KINDS OF DISEASE OF THE HARD TISSUE OF HUMAN TEETH, ESPECIALLY IN THE CARIES TEETH}

\author{
By \\ Moriyoshi MURAKAMI \\ Department of Anatomy (Director: Prof. Taneaki NAKAYAMA) \\ Kyushu Dental College, Kitakyushu, Japan
}

The research on the subject of splitting lines has a long history. Benninghoff and his school clarified the meaning of the splitting lines tentatively (1925). However, no interpretation has been presented by them about the irregular splitting lines that frequently appear and are observed in the line systems of the splitting lines. Prof. T. NAKAYAMA, M. D., (1957) attached special importance to the appearance of those irregular splitting lines and disclosed his study, offering the following opinion with regards to their significance. He concluded that the appearance of such irregular splitting lines is a direct functional manifestation that may be interpreted as a sort of defense reaction of the tissue, and insisted that the phase of growth of the organs and tissues should be grasped by the observation and investigation of both line systems and irregular splitting lines together.

Based on the opinion of Dr. Nakayama, the author has made a series of study in order to investigate whether or not such special irritations to the human tooth as dental caries, abrasion, attrition or operative dentistry would cause irregular splitting lines to the dentin of tooth as a defense reaction. The study has led the author to the following views:

1. In the case of human tooth, too, the appearance of the irregular splitting lines as a defense reaction was observed partially in the dentin.

2. The appearance of the irregular splitting lines was not observed on the surface of the dentin.

3. In the cross section of the tooth, no irregular splitting line was obsered at the superficial layer of the dentin, while both cases of appearance and non-appearance of those lines observed at the deep layer.

i) In the case of non-appearance, the reparative dentin formed as a defense reaction 
showed a small protuberance.

ii) In the case of appearance, the formation of the reparative dentin was odserved as a large protuberance.

As the cause of such difference, in the case ii) where the growth and formation of the reparative dentin is conspicuous, the growth force influences, as a component, the primary dentin insufficiently calcified in the course of development. The border line between the conspicuous reparative dentin and the deep layer of the primary dentin that come in contact with it makes a marked curvature, convex toward the superficial layer of the primary dentin. The splitting lines develop along this curvature and appear as the irregular ones, which is obviously odserved in the microscopic photo (fig. 8-b).

4. Appearance of the irregular splitting lines as a defense reaction, based on the Nakayama theory, is notably observed in the reparative dentin. There are two kinds of irregular lines that run to different directions seen among those lines, one of which is the lines developing along the edge of the rise of reparative dentin, and the others appear at a right angle toward the edge. When these two irregular splitting lines are observed togethor with the conditions of the caries, the former are seen appearing largely with the chronic, caries, while the latter appears of tener with the comparatively accute cases.

5. It is clearly observed in the microscopic photo (fig. $7,8,9$ ) that the development of all these splitting lines corresponds to direction of the main arrangement of fibrils of the dentin matrix on the surface of the dentin of the individual teeth examined.

From the way the irregular splitting lines appear in the dentin, the conditions of irritation the tooth sustained and the phase of growth of the reparative dentin formed as a defense reaction may be conjectured.

目次

I 緒 言

III料材抢よび研究方法

III 所 見

A 象牙質表面

B 縦断面

1. 䀞菌

2. 磨耗蔽

3. 咬耗歯

4. 充填処置歯

C 横断面

D 裂隙と象牙質基質繊維との関係

IV 総括ならびに考按

$\mathrm{V}$ 結 論

VI 文 献

\section{I 緒}

言

各種器官, 組織の分裂線に関する研究は, Dupuytren （1836）によって皮膚の裂妳性が研索されて以来，今日 まで多くの研究報告がなさ机て来た。 Benninghoff (1925)とその一閒の Georg Bessler1), G. Mauer2)らに より比較解剖学的にも研究がなされ, 骨緻密犋に怙ける 分裂線の意義が一応明らかにされた。すなわち分裂線は 学の発育構築を示すと同時に機能構築でああり，また必 然的に骨の外形によもなう形態構築をす示すむのである ことをのべている. Mauer (1933)2)は脊柱側彎症の機能 的適応敒関する研究の中で, 分裂線の上から椎骨を 3 型 に分類しその第 2 型として, 分裂線が不整な方向を示し ているととをすでに見ている。 また森（1954)13)，山根 (1956)14）らは骨折治瘉部における分裂線の所見の中で 不整裂線の存在を認めているが，何んら見解をのべては いない。しかし中山（1957）4）は従来の分裂線法による 研究に抢いて軽視されていたこの不整裂線の存在を重視 
し，その意義についても見解を与えた。乙れに基づいて 加令的変化汇関す研究が重称られ，その結果，てれら の不整裂線は骨質の示す一種の防禦反応之解される直接 的機能表現である之結論した。ささらに軟組織に扔いても この見解が成立するか否かが続いて检討され，線系と不 整裂線とをあわせて観察検討することによって，その器 官,組織の発育様相を把握すべきであると主張している.

一方人の歯について屯, Max Brodersen (1933)3), 三 枝 (1938)5)，山本 (1961)6) らによって分裂線による所 見が報告されている。しかしこれらの研究報告は歯の硬 組織に执いて特に疾患を見ないものについての所見であ る。

著者は中山の見解に基ついて，歯に対して特殊的な刺 激一外力ーである触蝕, 磨耗, 咬耗, 充填処置などによ り歯においても防禦反応之しての不整裂線の出現を認之 めるこが出来るか否かを検するため本研究を行なった。 さら潔線之象牙質基質繊維との関係をす合女て研索し た結果，與味むる所見を得たので報告する。

\section{III材料および研究方法}

研究材料に用いた人歯は，断面に书讨万所見の観察に 際して，その複雑性を避けるため前齿を選んだ。报去 後10\% Formalin 液にて1〜2週間 固定し，歯の表 面に付着する蒾石や残存せる軟組織を可及的に除去清掃 した，観察に供した函は抜去時生活歯䯣在有するすの

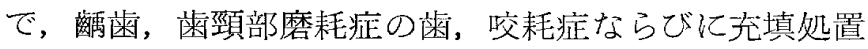
がなされた歯である。乙れらの歯を次の脱灰液にて5〜 7 日間脱灰した（脱灭液， $\mathrm{AlCl}_{8} 7 \mathrm{~g}, \mathrm{HCl} 7 \mathrm{cc}$, 水醋 酸 $5 \mathrm{cc}$ ，水 $100 \mathrm{cc}$ ）脱灰後は克分に水洗した，観察は醹 蝕病巣周围の象牙質表面抢よび断面について行なった。 縦断面の作製にあたっては，脱灭㐘を Cryostat 中で凍 結し，ミクロトームにより象牙質表面から除々に薄片之 して削除を行ない歯髄腔中央部に打汀万矢状断面招よび 前頭断面を作製した。乙机を実体顕微鏡下で注意潹く通 法のごとく針で穿刺し観察に供した，裂線之基質繊維の 関係を研索するために用いた歯は，穿刺後（墨汁は使 用しない) 凍結切片として Bielschowsky-Perdrau33) の渡銀法により渡銀した。また新鮮な抜去蒾を Iontophoress 29 ,30) による銀染色をなし，脱灰後穿刺して凍結 切片となし鏡検した。

\section{III 所見}

\section{A 象牙質表面}

畆歯の象牙質表面における分裂線の状況を観察するに あたって，先づ硬組織疾患が認めら机ない歯の象牙質表
面に抢ける分裂線の状況見る上，図」のA( $\sqrt{2}$ の遠心 面）に示すごとくである。すなわち線系は歯の外形にほ ぼ一致して，歯軸に平行的な縦走線系を示している，切 縁部求よび根尖部では，その尖端に線系は集約されて出 現し，特に切縁部では著明である。

この状沉をさらに些細に観察すると，菌軸に平行的な 縦走線系は歯の中央部に見られるI 線系（１）のみであ る．他はむしろ縦走斜裂線系を示している，すなわち歯 の輪廓部では，歯根舌側部を除いて，歯冠部㧍よび歯根 部之もに切緣之根尖に集約した歯の外形に沿う縱走斜裂 線系（2）を示している。菌根舌側部では斜走線系 (3) を現している．また歯冠舌側部の辺縁隆線に沿う部では 傾斜度は特に強く出現している。一般に裂線の傾斜度は 舌側半部が唇側半部に比して, 歯冠部歯根部ともに強く 認められる。

以上が硬組織涘患をともなわない菊の隣接面における 分裂線の所見である。

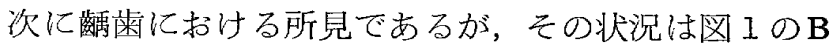
からDに示すごとくである，Bは厌の遠心隣接面に生 じた軽度の䀞蝕で䶜窩の形成はほとんど認められない。

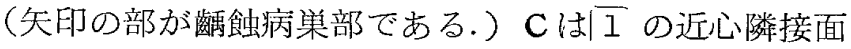

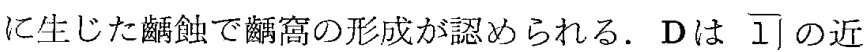

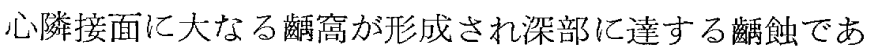

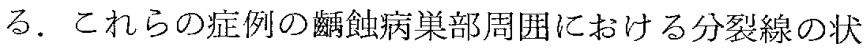
況は，図IのA之同椂で硬組織䛈患をともなわない㐘の 象牙質表面に扮ける所見上特に異った点は認められな

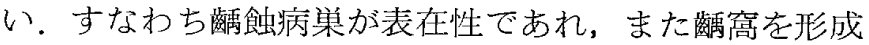
し深部に達するような症例であれ，いずれにも龄蝕病巣 周囲の象牙質表面では中山の見解に基づくところの防禦 反応としての不整裂線の出現は認められない.

\section{B 縦断面}

縦断面に括ける観察は，失状断面掞よび前頭断面につ いて，原生象牙質上第 2 象牙質之を区別して行なった。 第 2 象牙質については, 多くの名称之解釈がなされてい るが，ここで言う第 2 象牙質とは Orban の Reparative dentin を意味するすのである。

满歯の緹断面に抢ける分裂線の状況を観察するにあた り，先づ硬組織疾患をともなわない歯の矢状断面に見ら れる分裂線の状況を観察すると次のごとくである，図2 のAは上顎右側中切歯の矢状断面である。線系は抢扔よ そ歯軸に対して切縁を頂上し，順次歯根側輪廓部に向っ て傾斜をなす斜走線系（1）を示している。

萰冠部における斜走線系は歯根部におけるよりあその 傾斜度は強い，特に基底結節の部では著しい，しかし根 


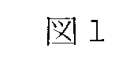

表面

龄蝕

写生怅

A
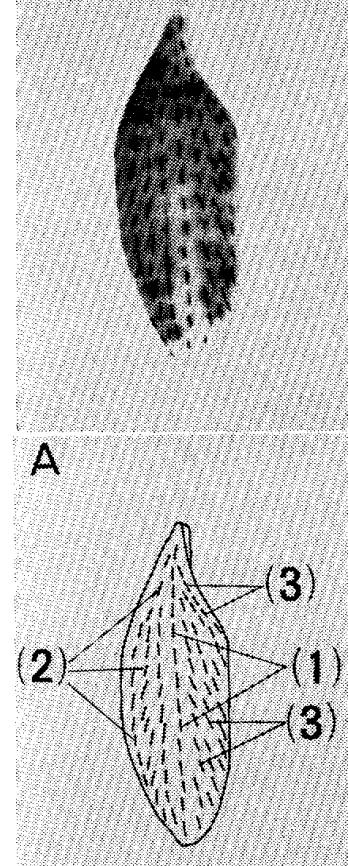

A
B

B

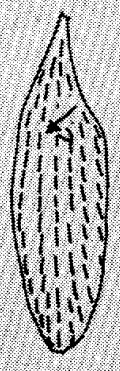

C

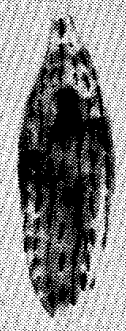

C

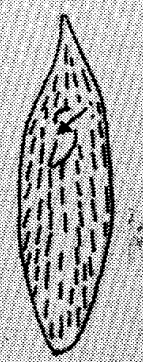

D

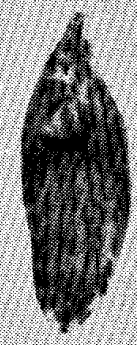

D

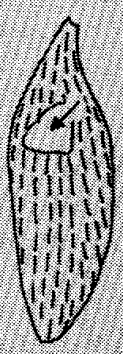

図2

縦断面

蹲蝕

写生図
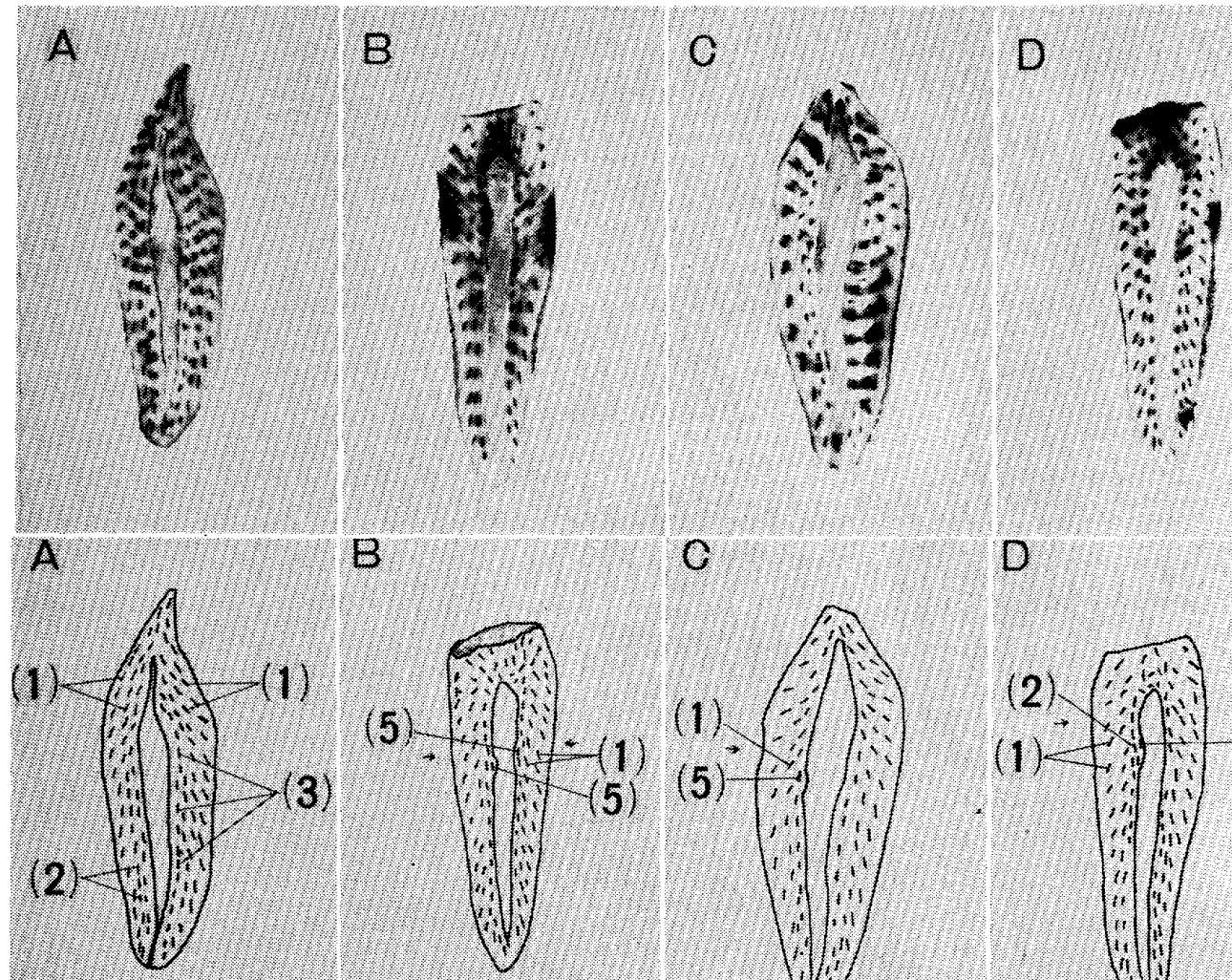

B

c

D
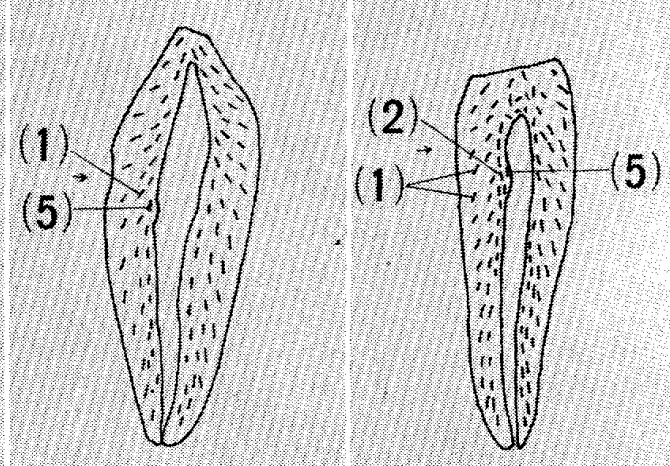


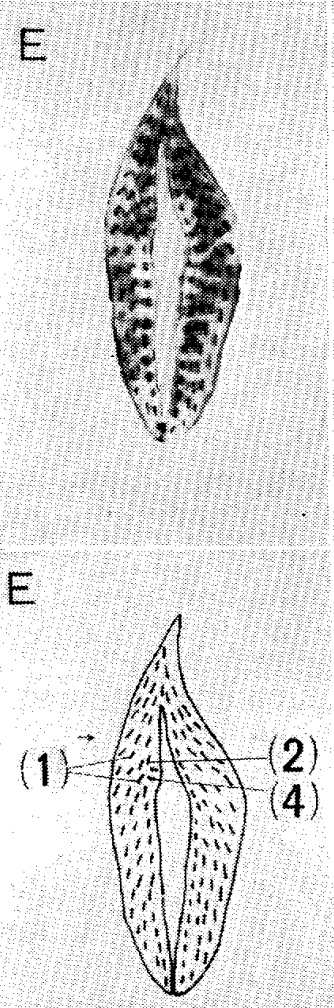

F

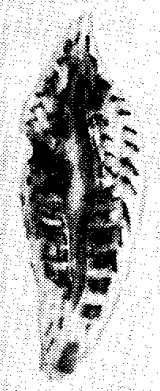

F

(3)

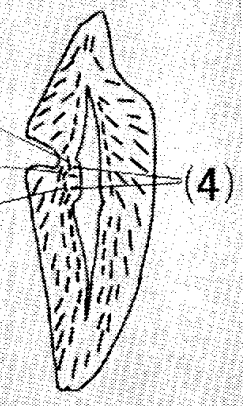

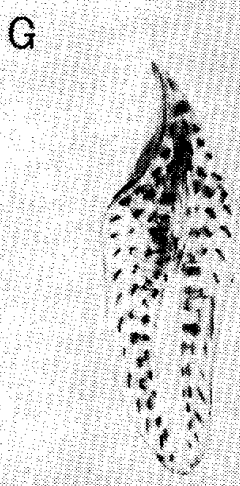

H

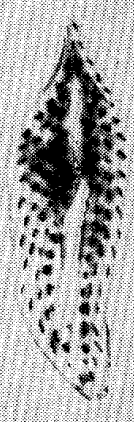

G舌側 唇側 H
(3) (rinis

$(1)-(1, y+x)=(1)$

(4)

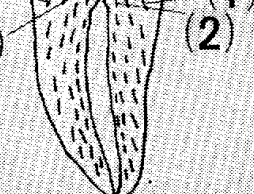

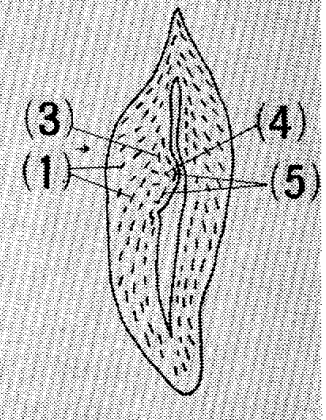

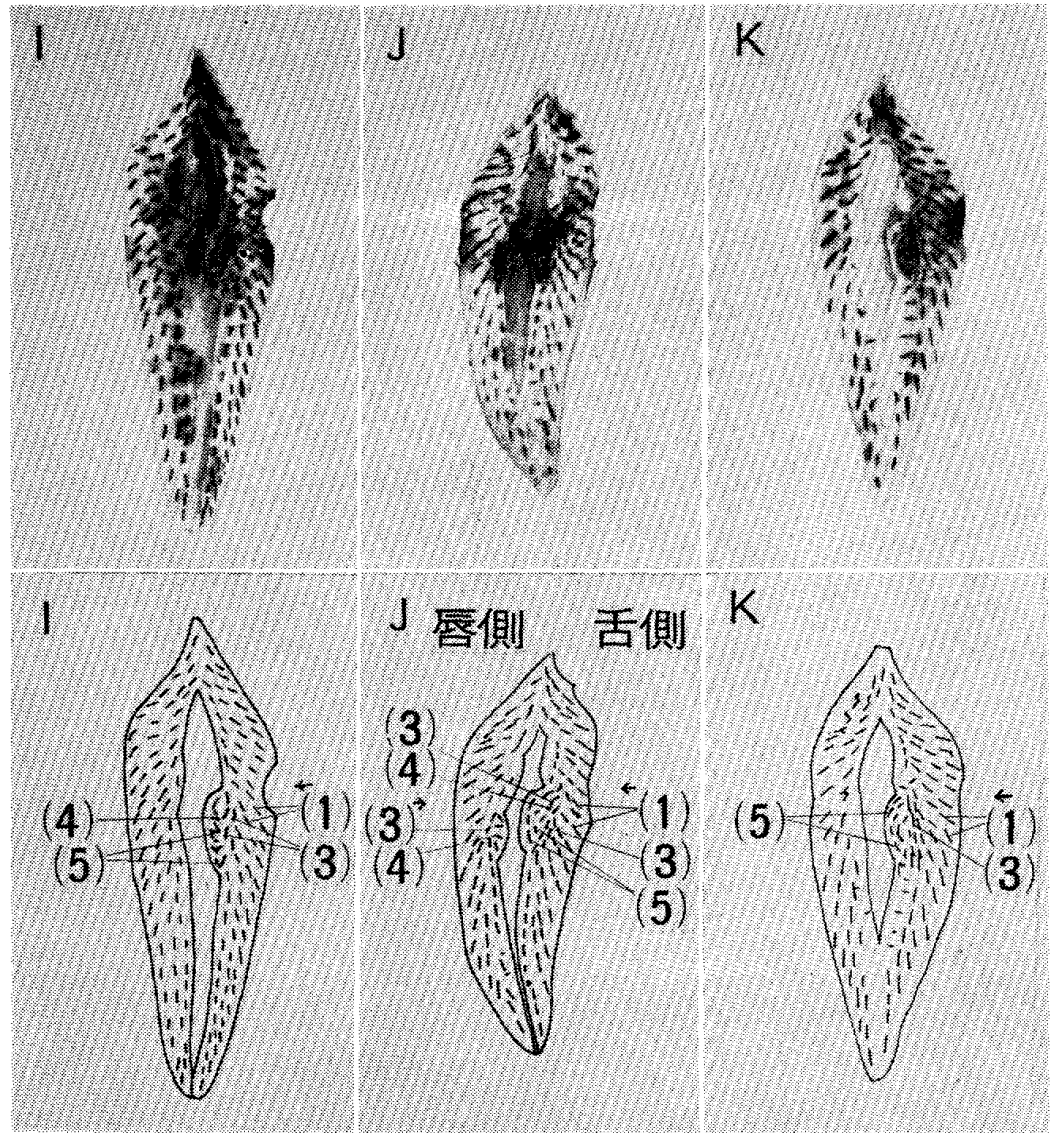


尖部ではむしろ歯軸に平行的な縦走線系（2）を示して いる，最内層の䯣腔壁の部では，䯣腔壁に沿った一連の 縦走線系（3）在示している。乙れらの裂線系の走行状 態は, V. Ebner の象牙層板模型上よく相似し, 岡田, 三村の醋酸鉛注射28)によって示された象牙質生長線に一 致した分裂線像を呈するものと考える。

以上が硬組織疾患をともなわない茵の矢状断面に㧍け る分裂線の所見の概略である.

1 龄䨑の縦断面に招讨る分裂線の所見

i) 原生象牙質

該部に打ける分裂線の状況は，明らかに象牙質の表層 部と，深層部でその趣を異にしている。すなわち図 20

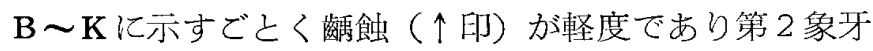
質の形成が小なる症例 $\mathrm{B} \sim \mathrm{E}$ であれ，敬蝕病巣が広範囲 に打よび䶔窩の形成が見られ，第 2 象牙質の形成が隆起 として認めら机る症例 $\mathrm{F} \sim \mathrm{K}$ であれ，いずれもその表層 部の線系は，硬組織聅患をともなわない歯の原生象牙質 において観察された所見之全く同様に，斜走線系（1） を示し䶗蝕による不整裂線の出現は認められない，とこ ろが深層部ではその趣を異にする。すな打ち広範な袘蝕 症巣が見られる症例，あるいは大なる䶘简の形成が認め られる症例では，第 2 象牙質の形成が著明な隆起として 髄腔内に突出し，乙机に接する原生象牙質深層部に乱れ を示す一群の不整裂線（3）加認的られる（図2のF $\sim \mathrm{K}, \mathrm{G}$ は舌側) てれらの症例について脱灰前に招ける 齫蝕の状沉を見ると，Fは歯頸部に磨耗を生じ，さらに

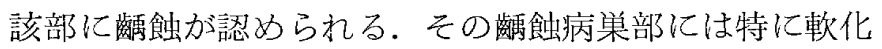
象牙質が多量に認められ，比較的急性婳蝕の経過を取。 たものと思わ机る， G， H， J (唇側) は，エナメ儿質 に扔いて比較的広範囲に浅い龇窩の形成が認められ，病

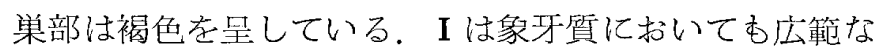

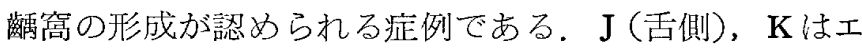
ナメル質に扔ける唃窝の形成は比較的浅く軟化象牙質屯 少く，歯質の広範囲加暗褐色洋着色していることから， 比較的慢性齫蝕の経過を取った症例と思われる，との上 うに第 2 象牙質の形成が大なる隆起として認められる症 例に扔いてのみ原生象牙質深層部に不整裂線の出現を認 め得る。しかし J， Kのごとく比較的慢性の経過をとっ たと思われる症例では，その出現は軽微である。ただし 深層部であっても㽬蝕が軽度で第 2 象牙質の形成が比較 的弱い症例，図 2 の $\sim \mathrm{E}$ 㧍よび $\mathrm{G}$ (唇侧) では，その 線系に特に変化認好難い.

ii) 第 2 象牙質

該部は象牙質の内層部で刺激に対して防禦反応として
新たに形成された象牙質である。該部においては図B～ Kに見られるごとく不整裂線（4)，（5）の出現が著明 に認められ，しかむそれらの不整裂線には，裂線の方向 を異にする 2 種が区別される。すなうち第 2 象牙質隆起 の辺縁に直交的な裂線（4）上, 隆起の辺縁に平行的な 裂線（5）乙が垫められる。乙れを第 2 象牙質の形成状 況とあわせながら些細に観察するに次のごとくである。 隆起の形成が小なる症例のうちには，Eで見られるで之 く隆起の辺縁に直交的な裂線（4）を示す屯のと，B〜 G (唇側) に見ら机るごとく隆起の辺縁に平行的な】〜 2 の単純な裂線（5）を示すものとがある。

第 2 象牙質隆起の形成が比較的大なる症例では F に見 られるごとく隆起の辺縁隹真的な裂線（4）のみが認 められる症例之， $\mathrm{G}$ (舌側)，H，Iに見られるごとく 裂線（4）の内側（随腔側）部にさらに裂線（5）の出 現が認められる症例，すなわち隆起の辺縁に直交的な裂 線之辺縁に平行的な裂線之が同一隆起内に認められるむ の，ならびに J (舌側)，Kに見られるように隆起の辺 縁代平行的な裂線（5）が工〜2 連の弧状線系化の傾向 を示す症例之が区別されるのである。なお

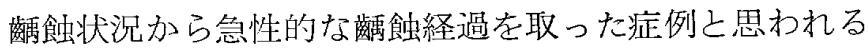
が，第 2 象牙質の㲽縁值真的な裂線 (4) が限局して 認めら机る，J，Kは比較的慢性硧蝕の経過在取った之 思利る症例であり，第 2 象牙質隆起の辺縁に平行的な 裂線（5）が広範囲に認められる。また $\mathrm{G}$ (唇側)， $\mathrm{H}$ ， Iでは裂線（4）の内側（髄腔側）部に裂線（5）か認 められる。

2 磨耗蒾の縦断面に抺ける分裂線の所見

磨耗症は機械的摩擦により歯の硬組織の一部が久損し

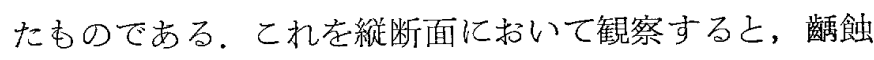

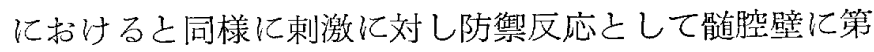
2 像牙質が形成され隆起として認められる。

本症に扔故分裂線の状況は図 3 の A E に示すごと くである。（个印は磨耗によりクサビ状欠損を生じた部 分である。）

i）原生象牙質表層部

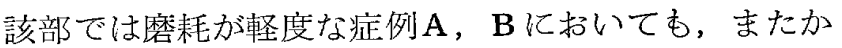
なり大なるクサビ状欠損が見られる症例 $\mathrm{C} \sim \mathrm{E}$ に扔いて あ分裂線の状況は婳歯の原生象牙質表層部で観察された 所見之全く同様に，線系の乱れは認められない。すなわ ち硬組織疾患を見ない歯の原生象牙質表層部が示す斜走 線系（1）を現している。

ii) 原生象牙質哚層部

該部では磨耗が軽度で第 2 象牙質の形成す比較的小な 
四 3 磨耗症

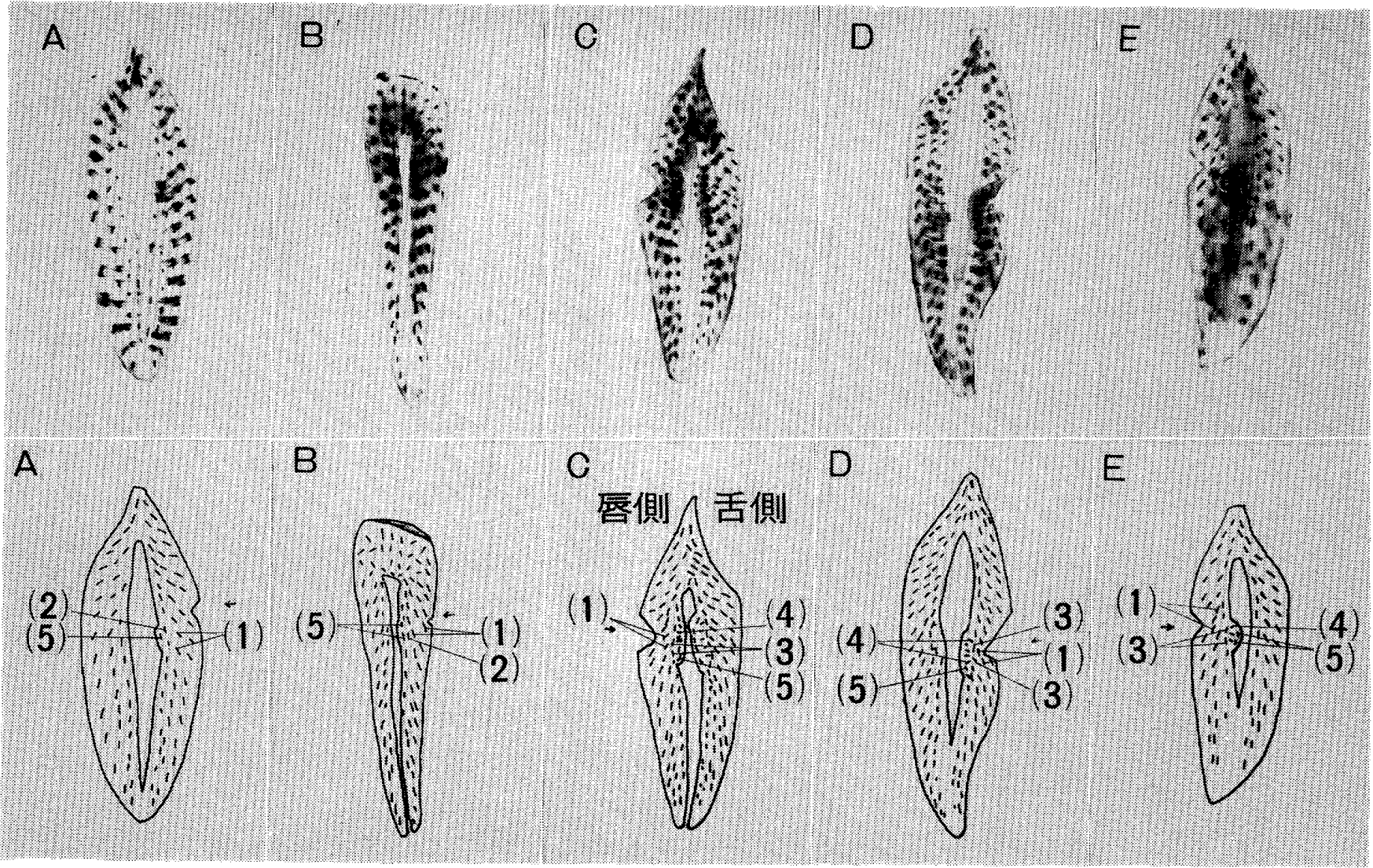

写生図

る症例 A， Bに扔いては, 線系に変化は認められず韧道腔 壁に沿って出現する一連の縦走線 系 (2) が認められ る. しかし磨耗が更に進み歯質の欠損が大上なり，第 2 象牙質の形成毛著明な隆起として認めら机る症例 C E

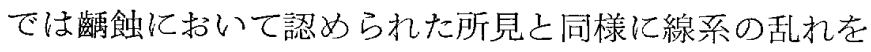
示す不整裂線（3）の出現が認められる.

iii) 第 2 象牙質

該部に抢ける裂線の状況は，図 3 の A E (C は唇側) に見られるごとくである。すなわち磨耗が軽度で第2 象 牙質の形成屯小なる症例 $\mathrm{A}, \mathrm{B}$ では第 2 象牙質の隆起の 辺縁に平行的な裂線（5）がエ〜2認められる。 また大 なるクサビ状火損が認められ第 2 象牙質も大なる隆起亡 して形成された症例では，不整裂線（4)，（5）の出現 が著明に認められる。乙れは路蝕に抢ける所見之同様 であるが，慢性的な龇蝕に見られたごとき裂線（5）が エ〜2連の孤状線系化の傾向を示す症例は見ら机ない.

3 咬耗歯の縦断面に打ける分裂線の所見

咬耗症に打ける分裂線の状況は，図 $40 \mathrm{~A} \sim \mathrm{F}$ に示す でとくである。(个印は咬耗の部である)

i) 原生象牙質表層部

該部における分裂線の状沉には，特に線系の変化は認
められない。すなわち巍蝕抢よび磨耗症に抢いて観察さ れた所見と同様汇斜走線系（I）を示している.

ii）原生象牙質深層部

該部に打ける分裂線の状況は，齵蝕および磨耗症に掞 けるごとく明確には不整裂線を認め得ないが，咬耗度の 強い症例 C〜Fに拈いては乱狄示す傾向の裂線( 僅加に認められる。

iii) 第 2 象牙質

本症に沶いてす雬質の欠損に対して，防禦反応として の第 2 象牙質が檤腔内に形成され不整裂線の出現が認め られる. 図 4のA〜C は下顎犬歯であるが第 2 象牙質 は䯣腔内に乫出する隆起ではなく, 尖頭あるいは切縁に 相当する䯣室角を充す状態で認められる。図 4 のD〜 F は上顎犬歯で第 2 象牙質は䯣室の舌側壁牦起して認め られ，このような D Fでは隆起の辺縁に沿う裂線 (4) が 〜 2 連の孤状線系化の傾向を示している，他方髄室 角が允されているA〜Cでは，前記の傾向は認められな いが，笠耗の進行方向之平行的に出現する裂線（4）上 乙れに直交的な裂線（5）とが認められ，裂線（5）は 髄空壁辺縁部において比較的多く出現している. 

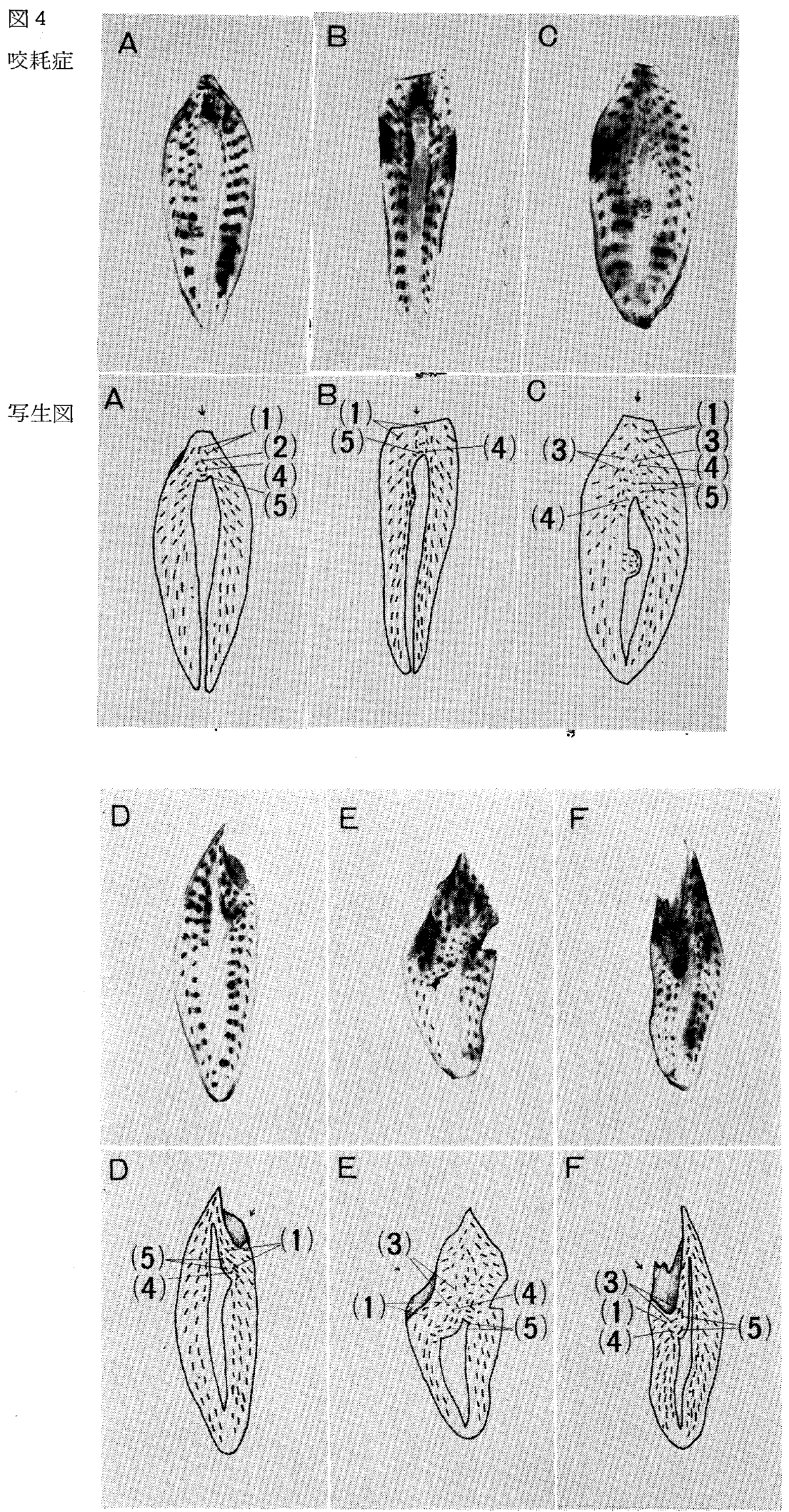


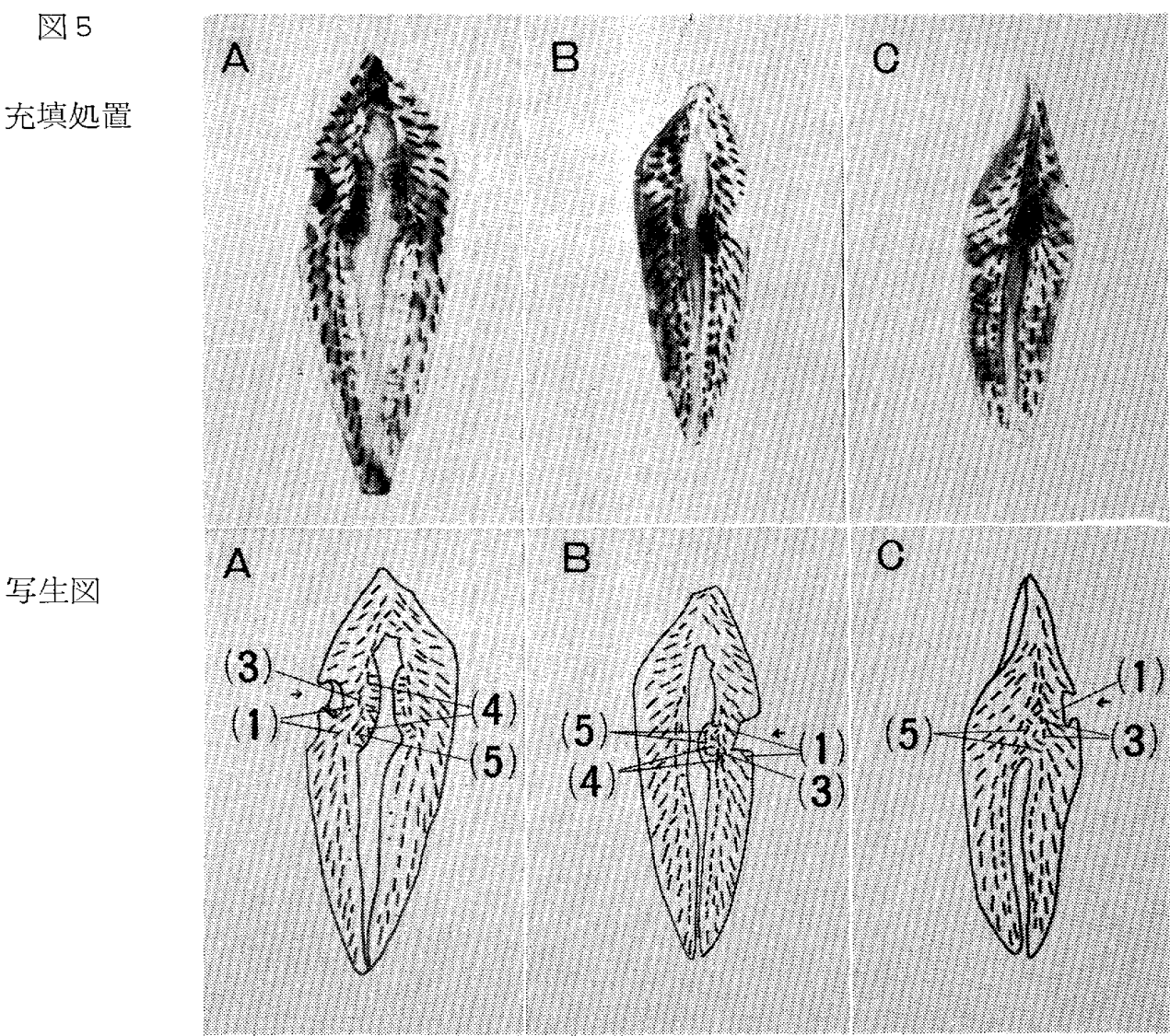

4 充填処置菌の縦断面に戈ける分裂線の所見 研究に用いた克填処置歯の脱灰前に扣ける状況は, 図 5 の〜Cいづれも金属充填がなされ，Aに打いては充 填物の辺縁より2 次䶖蝕の発生が認められた。

（个印が充填処置がなされた部である。）

i) 原生象牙質表層部

該部に招ける分裂線の状況は，図 5 のA〜Cで見られ るごとく不整裂線の出現は認められない。すなわち斜走 線系（I）を示している.

ii) 原生象牙質深層部

該部に抢ける裂線の状況は，図5のA〜Cに抢いて見 られるごとく䶕蝕, 磨耗症などの歯で観察された所見之 同様に不整裂線（3）の出現汃認力られる。

iii) 第 2 象牙質

該部に扔いては，不整裂線の出現が著明に認められ る。すなわ第2 象牙質隆起の辺縁任直交的陆出現する 裂線（4）之，隆起の辺縁に平行的な裂線（5）上が認 めら机る。乙れらの裂線の出現状況を，各症例について 観察すると，Aでは第 2 象牙質隆起の辺縁に直交的に出 現する裂線（4）によってほとんど充さていれる。

しかし注意深く観察する己，これらの裂線（4）の外 側 (原生象牙質側) 部，すなわち初期に形成された之思
われる部に隆起の辺縁に平行的な裂線（5）の出現が僅 かながら認められる，Bでは第2 象牙質隆起の辺縁に直 交的に出現する裂線（4）上， その内側（髄腔側）部に 隆起の辺縁に平行的な裂線（5）とが認められるが, 後 者は一連の孤状線系化の傾向を示している。乙の状況は 䠘歯で観察された図 2 の $\mathrm{G}$ (舌側) 〜 I に招ける状況之 相似た所見である。Cでは前者A，B の所見とはまた異 なり，第 2 象牙質の辺縁に平行的な裂線（5）はュ〜2 連の弧状線系化の傾向を示している。乙の状況は，齓歯 の慢性経過取ったと思われる図 2 の，Kに打汀る所 見亡よく似通っている。

\section{C 横断面}

龂蝕, 磨耗症の歯の横断面に括ける分裂線の状況を観 察するにおたって，先つ硬組織疾患を己もなわない菌 の横断面に扮ける分裂線の状況を見る之，図 6 の A 亿示 すごとくである，該歯は上顎左側中切歯で米頸よりやや 歯根側の部で横断されたものである。一般に象牙質表層 部に抢いては蒾髄腔を中心として表面に放射状の裂線（ 1）が認められ，その内側の梁層部では，歯䯣腔を中心 とした同心円性の裂線（2）が認められる。輪廓が隆起 した部や㟵隆している部分では特に放射状の裂線が著明 に出現している，また歯冠部之歯根部では上記の裂線の 
沧 6

横断面

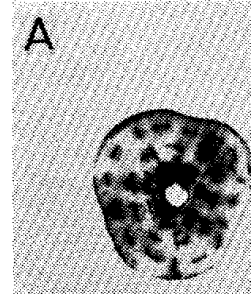

軍生図

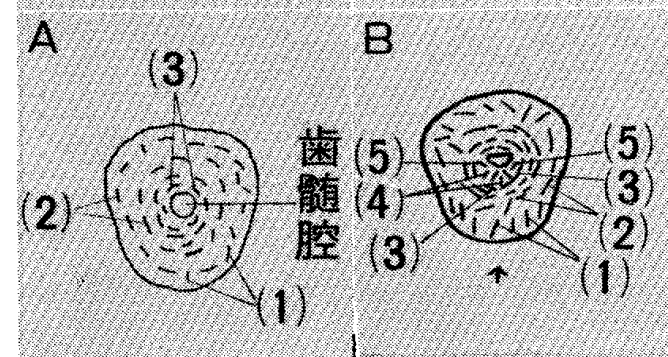

E

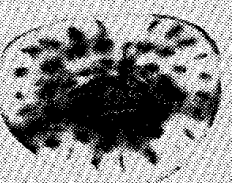

E

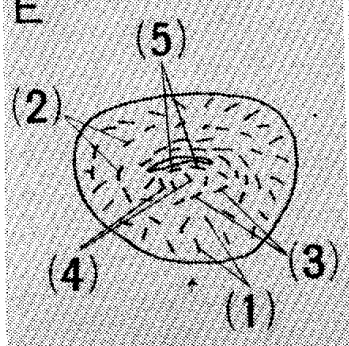

F (2)

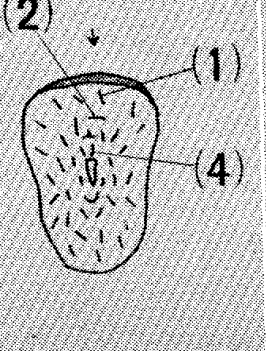

C

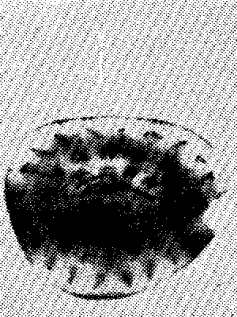

D

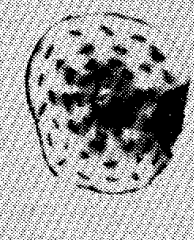

C (5)
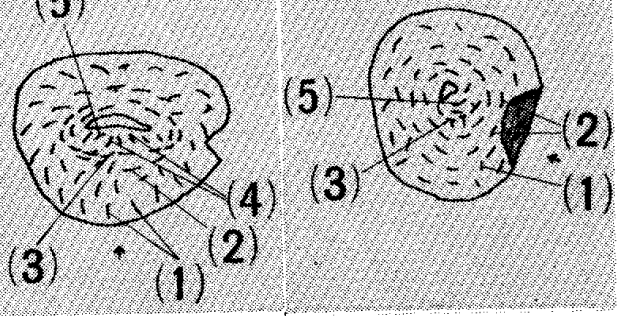

2)
G
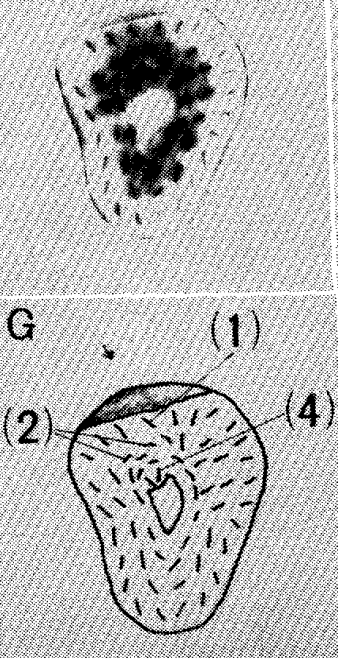

H
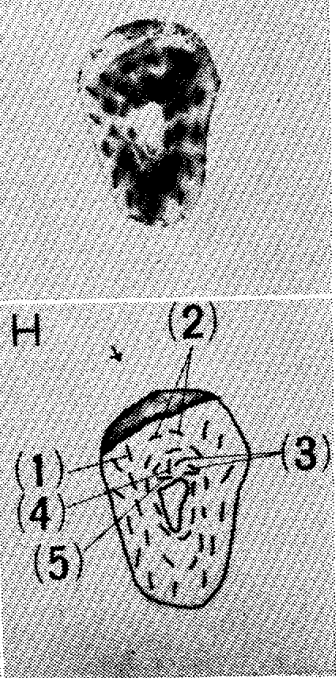

出現状況が著しく異なる。すなわち株冠部では放射状の 裂線の出現領域は広範囲であり，同心円性の裂線は䯣壁 周辺部の小範囲に認められるのに対して，歯根部では逆 に同心円性の裂線が広範囲に出現している。乙れは縦断 面に抏いて観察されたどとく, 歯冠部に扣ける斜走線系 はその傾斜度が雪根部に抬けるすのより強く, 䯣壁周辺 部において估かに縦走線系が認められたとと, 歯根部で は傾斜度は弱く，しかも縦走線系の出現する領域が拡大 していたてとなどから，横断される位置によって裂線の 出現状況に差異が認められるととは容易に理解されると 亡と考える。

以上が硬組織疾患をともなわない歯の横断面に出現す る分裂線の一般的状況である.

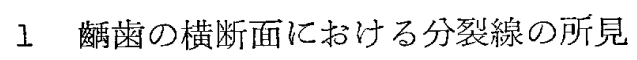

\section{i) 原生象牙質表層部}

該部における裂線の状況は，図6のB〜Eに示すごと く, 特にその所見に变化は認められない。( の進行方向である).

ii) 原生象牙質深層部

該部においては縦断面で観察されたと同様に不整裂線 (3) の出現が認められる.

iii) 第 2 象牙質

横断面においては，第 2 象牙質は䋛断面におけるよう に明瞭な隆起亡しては認められないが, 不整裂線の出現 は著明に認为られる。すなわち図6のB，Cは第 2 象牙 質隆起の迅緣に直交的な裂線（4）が限局して出現し, その両端部には隆起の辺縁に平行的な裂線 (5) が散見 される。これは縦断面では明確には認められなかった所 
見である。D，Eでは隆起の辺縁に平行的な裂線（5） の出現が広範囲に認めら机, 直交的な裂線（4）はその 限局性を減じ散在的に認められる。乙れは巍歯の縱断面 図 2 の $\mathrm{G}$ (舌側) 〜 I に扔ける状況上相似た所見であ る.

2 磨耗歯の横断面に扮ける分裂線の所見

i）原生象牙質表層部

該部における裂線の状況は，図6のF〜Hに示すご上
く，特にその線系に変化は認められない。

ii）原生象牙質樑層部

該部における裂線の出現状況を見ると， F扔よび $\mathrm{G}$ は線系自体の乱れを明確には認め難いがHにおいては不 整裂線（3）の出現が僅かながら認められる.

iii) 第 2 象牙質

該部においては，不整裂線の出現が明確に認められ る，F，Gでは隆起の辺縁に直交的な裂線（4）のみが

\section{B}

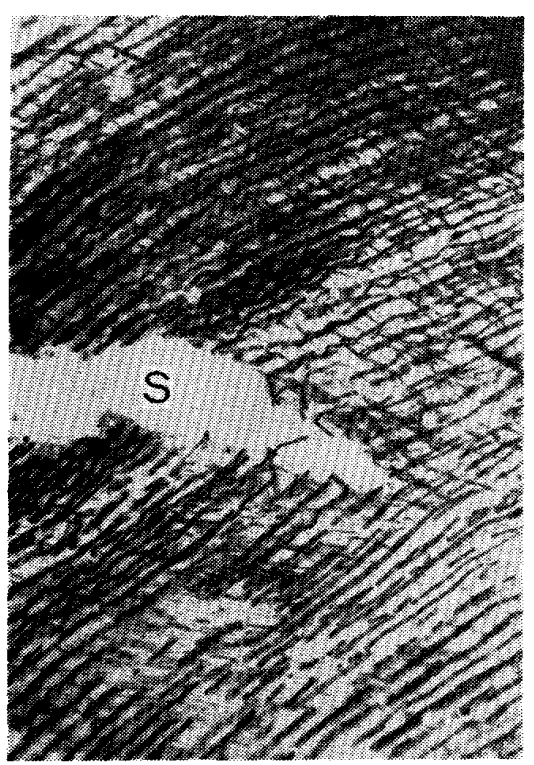

図 7 A，B共に㐘の縦断標本. Iontophoress による銀染色。図の左下より右上 方に維断された象牙管細が走り，乙れと交叉して束状に黒染して見られる 基質繊維と裂隙 $\mathbf{S}$ は一致した方向に生じている。×400

$\mathrm{C}$

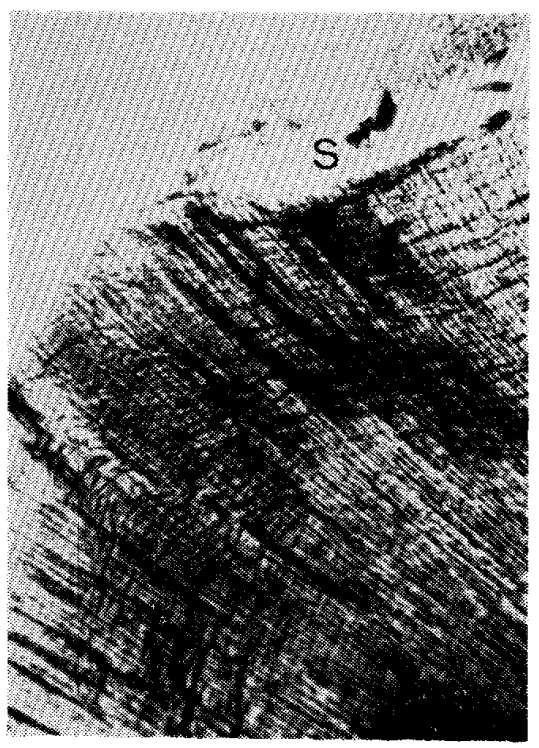

D

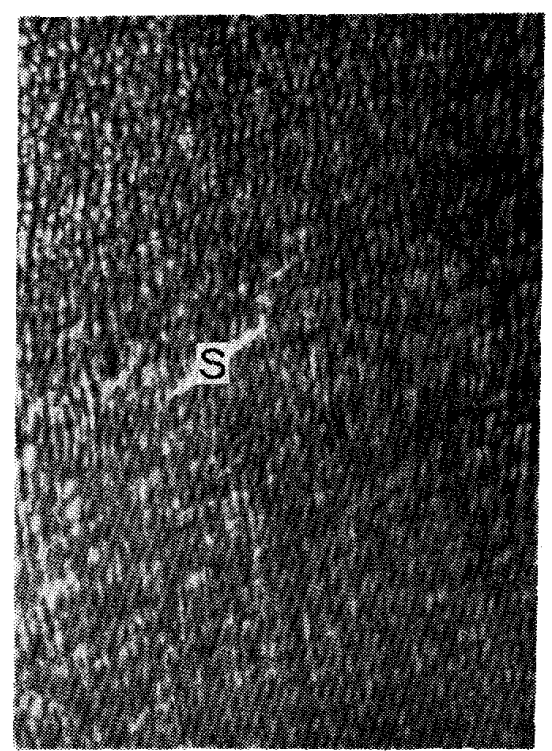

図 $7 \quad \mathrm{C}, \mathrm{D}$ は共に歯の横断標本。Cは Iontophoress 亿よる銀染色．Dは鍍銀 染色. 図の上方が象牙質表面である。象牙細管はCでは縦断され右下より 左上方に走っている。Dでば図の上部は横断されているが,下部は斜断さ 机縦の方向に走っている。裂隍 $\mathbf{S}$ はこ机之交攴して走る基質繊維の配列方 向に一致して生じている。C 
認められ，Hにおいては辺縁に值交的な裂線（4）は僅 かであるが，その内側（䯣腔側）部にさらに辺縁に平行 的な裂線 (5) が認められる.

D 裂陌之象牙質基質繊維之の関係

\section{I 原生象牙質表層部}

図７のA〜Cは Iontophorse に上る銀染色，D恔 銀染色によるものである。A，B は縦断標本で図の右側 が象牙質表面である，左下より右上方縦断された象牙 細管が走り，乙れ之交义して束状に黒染して見ら机るの

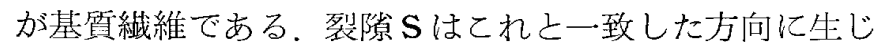
ている，C，Dは横断標本で図の上方が象牙質表面であ る. 象牙細管は，Cでは縦断されて右下より左上万に走 っている。Dでは，図の上部は横断されているが，下部 では斜断され縦の力向に走っている。裂隙 $\mathrm{S}$ はいづれも 象牙細管上交叉して走る基質繊維の配列方向に一致して 生じている。

\section{2 原生象牙質深層部}

図8のA，B継断標本の鍍銀染色によるあので，左 下方が䯣腔側である。A は第 2 象牙質の玥成が著明な隆

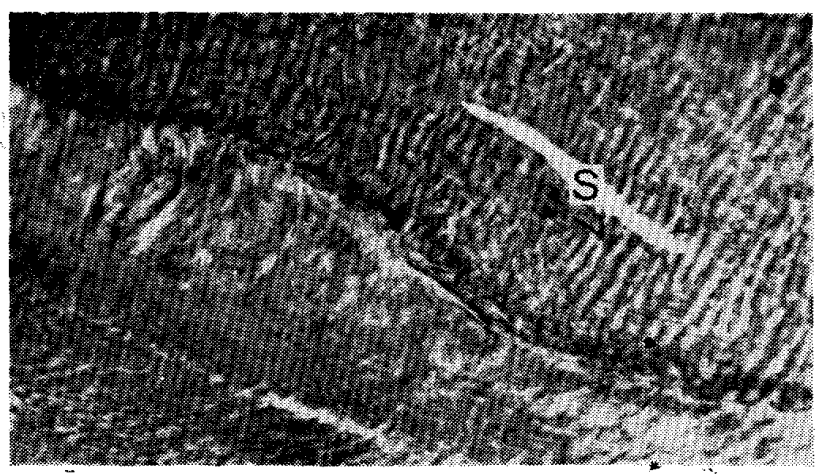

図8 歯の縦断標本. 鍍銀染色. 第 2 象牙犋の形成

A が著明な隆起亡して認められる標本で，図の 右上部の原生象牙質亡, 左下部の第 2 象牙質 との境界線が中央部で著明な彎曲をなし斜め に走っている。原生象牙質の象牙細管は縦断 され，乙れと直交的に基質繊維は配列してい る。裂隙 $\mathbf{S}$ はの配列方向之一致し境界線の 租曲に沿って生じている。 ×400

起として認められる標本である. 右上部の原生象牙質 之，左下部の第 2 象牙質上の境界線が図の中央部で著明 な彎曲をなし斜めに走っているが，第 2 象牙質の象牙細 管が縱断むしくは斜断された部が図の中央部で特に広く 見られるがこの部で境界線の彎曲は象牙質表層部に向っ て凸彎をなしている，基質繊維は縦断された原生象牙質 の象牙細管之直交的に配列して認扔り，裂隙 $\mathrm{S}$ はその 配列方向々一致し，境界線の彎曲に沿って生じている。 この状況は該部に括ける分裂線を観察した際に第 2 象牙

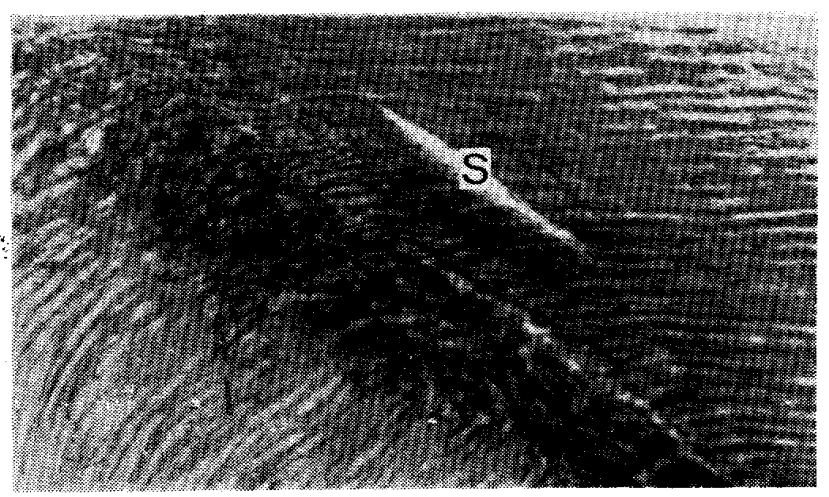

図 8 粜の縦断標本. 鍍銀染色. 図の左下方が骨迶腔 B 側, 中央部に象牙細管の走行が不規則な状態 を示す第 2 象牙質が見られ，その形成の程度 は僅少である。左下部は象牙前質，右上部は 原生象牙質である，原生象牙質の象牙細管は 縦断されて横走し，基質繊維はこれと交叉し て走り，裂隚 $\mathbf{S}$ はその力向に一致して直線的 に生じている。 ×400

質の形成が大なる隆起として認められた症例において， 裂線に乱れが認められた状況を示すあのと思われる。B の左下部は象牙前質，右上部は原生象牙質である。図の 中央部に象牙細管の走行が不規則な状態を示す第 2 象牙 質が見られるが，その形成程度は僅少である．原生象牙 質の象牙細管は縦断されて横走しており，基質䋐維は束 状をなしててれ之交叉し黒染されている。裂陌Ｓはその 万向に一致して直線的に生じている.

\section{3 第 2 象牙質}

図 9 の〜Dは繒断標本を鍍銀染色したあのである. 図の左方がすべて髄腔側である。A は象牙細管が斜断 され白く始けて見える，その数も少なく基質繊維の配列 はかなり乱れた状態を示しているが，主配列方向は象牙 細管の斜断された方向に見られ裂隙 $\mathbf{S}$ はその走行に一致 して生じている。この裂隙の状況は，第2象牙質に括け る分裂線のうち隆起の辺縁に直交的な不整裂線を示すむ のであろう．BはAの部に隣接する内側部すなわ赑䯣腔 側であるが，象牙細管が縦断され白くぬけて見える．基 質繊維は象牙細管上斜めに交叉し，裂隙 $\mathbf{S}$ はその配列方 向に一致して生じている。Cは図の右下方が原生象牙質 の深層部である，左上方に䯑道焢が見られ，図の中央部に 不規則な走行を示した象牙細管が縦断むしくは斜断され ている，基質瀻維の配列状態は不規則ではあるが主配列 方向は象牙細管の走行する方向に見られる．原生象牙質 との境界部では，象牙細管之交叉して見られ第 2 象牙質 隆起の辺縁に平行的な走行を示している．裂吵Ｓは瀻維 の配列する主方向に一致し鈎状に生じている，従来，象 


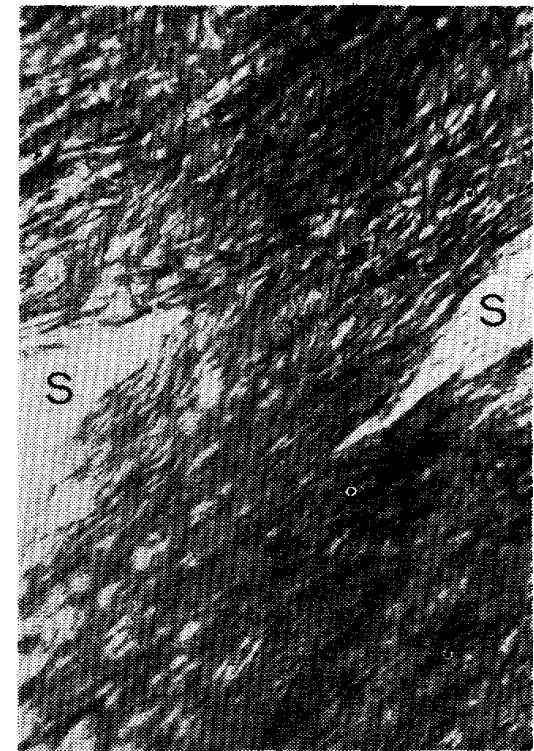

図 $9 \mathrm{~A}$ 歯の縦断標本. 鍍銀染色. 第 2 象牙 質の部である。象牙細管が斜断され 白くぬけてみられる。原数も少な く基質繊維の配列はかなり乱れた状 態を示しているが主配列方向は象牙 細管の斜断された方向に見られ，裂 隙はその方向に一致して生じてい ろ. $\times 400$

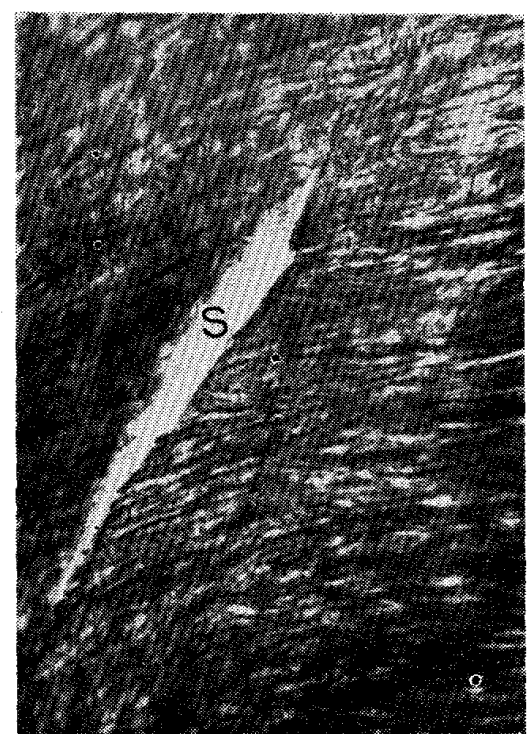

図 9 B 㐘の紛断標本. 鍍銀染色. A の部に 隣 接する内側部である. 象牙細管 が縦断され白くぬけて見られる。基 質繊維は象牙細管と斜めに交文し, 裂隙 S は纎維の主配列方向と一致し て生じている。 ×400

牙細管と基質繊維の配列状態との関係については多くの 見解がのべられて来たが, 今日では基質繊維の走行は象 牙細管に対して, 直交もしくは斜佼叉し象牙質の成 長線に一致した方向に配列し象牙細管之平行的な配列状

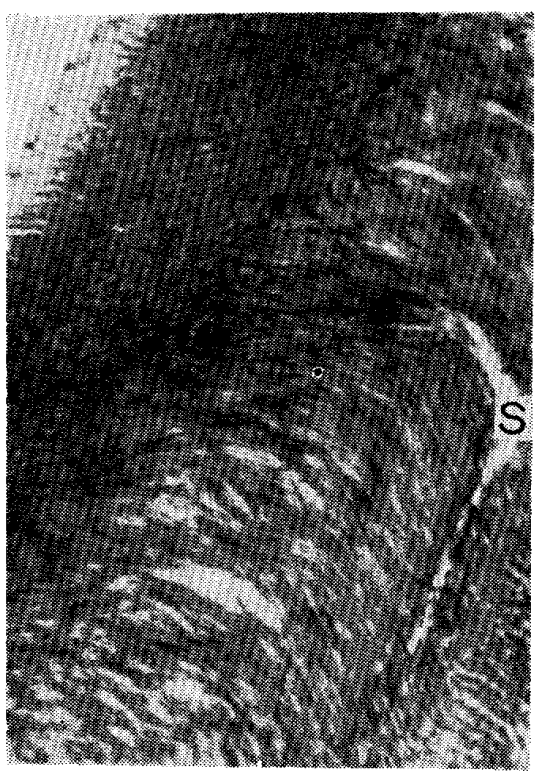

図 $9 \mathrm{C}$ 歯の縱断標本. 鍍銀染色. 第 2 象牙 質の部である.図の中央部に不規則 な走行を示した象牙細管が縦断むし くは斜断されて見られ，基質繊維の 配列状態は乱机ているが，主配列方 向は象牙細管の走行する方向に見ら れる. 右下方の原生象牙質との境界 部では象牙細管と直交的な配列を示 し. 裂隐 $\mathbf{S}$ は繊維の走行に一致して 鈆状に生じている。 $\times 400$

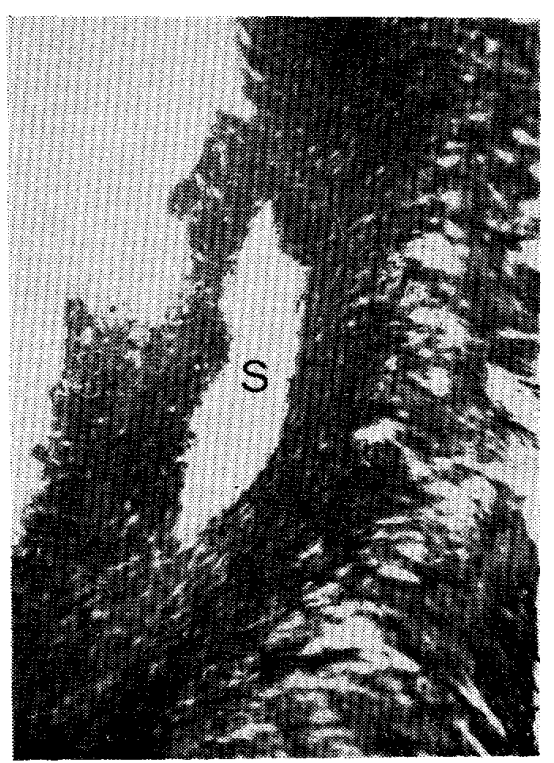

図 9D㐘の縱断標本. 鍍銀染色. 第 2 象牙 質隆起の辺縁部で図の左方が随腔で ある。象牙細管が斜断され白く好 て見られる。裂隙 S は第 2 象牙質隆 起の辺縁に沿った主配列方向を示す 纎維の走行と一致した方向に生じて いる、 $\times 400$ 
態は示さないものとされている。一条18)は第 2 象牙質の 一部に抢いて象牙細管に平行的な配列を示す繊維が見ら れたとのべているがこのような部であろうと考えられ る。D海第 2 象牙質隆起の辺縁部の標本である。象牙細 管が斜断されて白くぬけて見られる裂隙 $\mathrm{S}$ 第 2 象牙質 隆起の辺縁に沿って主配列方向を示す瀻維の走行と一致 した方向に生じている。乙の裂隚は第 2 象牙質に打りる 不整裂線のうち隆起の辺縁に平行的な裂線を示す状態で ある。

以上原生象牙質の表層部之深層部ならびに第 2 象牙質 に㧍ける裂隚之基質緎維の配列状態との関係について観 察したが, 裂陌はすべてその断面における繊維の主配列 方向に一致して生じている。

\section{$\mathrm{V}$ 総括ならびに考按}

以上蛄蝕, 磨耗症, 咬耗症ならびに充填処置がなされ た歯に打ける分裂線の状況を中山の見解に基づき, 防 禦反応としての不整裂線の出現状況に主眼を扔いて観察 検討を行なって来たが，乙こで図】〜10にしたがい総括 的考察を行なうに次のでとくである。

\section{1 象牙質表面}

図」のB〜Dで観察されたごとく象牙質表面において は，满蝕度の軽重にかかわらずいわゆる健康歯の象牙質 表面に出現する線系と全く同様の所見を呈している。す なわ菊の中央部に歯朝に平行的な一連の縦走線系 (1) を認め，その唇側执よび舌側部では切縁と根尖に集約的 な歯の外形飞沿う縦走斜裂線系 (2) と斜走線系 (3) とが認めら机る。すなわち象牙質表面には中山の見解に 基づくところの防禦反応としての不整裂線の出現は認め られない。

2 断面（緹断，横断）に扔订る原生象牙質表層部 該部に抢いても図2〜6亿抢いて観察されたでとく， 防禦反応としての不整裂線の出現は認められず，いわゅ る健康歯の原生象牙質表層部に出現した斜走線系 (I) が認められる。すなわち象牙質表層部では，その断面に 出現する分裂線からは防禦反応としての直接的機能表現 上解される不整裂線は認められない。では象牙質表層 部に扔いて唃蝕やその他の刺激に対して全く防禦反応が 認めら扎ないかというと，事実防禦反応であると考えら 机るところの研究報告がなされている。粟沢25) らは実験 的に㽬玲病巣周囲の象牙質に抢いて，2次的に銀好性原 繊維の出現を認好，乙れは象牙質の示す生体防禦の生理 反応であるとのべている，Goto27) は Microradiograph により龋蝕のため溶解された象牙質に再石灰化層を認め
ている。また路蝕病巣部に透明象牙質が見られること は17)象牙質に加わる刺激に対して生理反応が示すところ の一種の生体防禦である.かかる防禦反応が分裂線の所 見の上からは全く認められないということは, 基質瀻維 の配列状態に変化が生じていないもの之考えられる。乙 のととは, 歯の機能的形態ならびにその歯周組織の状態 によるあのであろうと考える。すなわち歯冠部ではエナ メル質により被覆され，歯根部ではセメント質により， さらに歯槽壁によって被覆されており象牙質は直接咬合 圧を受けることはない，しかむ基質紼維は象牙質成長面 上を子午線状に成長線に一致して走り, 歯冠部では咬合 压の方向に対して扔よそ直交的な配列状態を示してい る。歯根部では歯軸に対してほぼ水平的である。これは 㐘の水平方向の動摇に対し直交的な配列状態を示してい る.このように組織構造においてすでに合目的的に形成 されているため発育成長が完了した象牙質では，剌激に 対しその基質繊維の配列状態には変化が起り難い屯のと 考える。

3 断面 (縦断, 横断) 飞招讨る原生象牙質深層部 該部に扮ける分裂線の所見は図 2 ～6で観察されたご 之く, 第 2 象牙質の形成が軽度の症例では線系の乱れ， すなわち不整裂線は認められずいわゆる健康雪が示すと ころの髄腔壁に沿って出現する縦走線系 (2) を示して いる、ところが齸蝕, 磨耗, 咬耗などがさらに進行し䯣 腔内に第 2 象牙質の形成が大なる隆起として認められる 症例に抬いては，該部の線系に乱机示す不整裂線(3) の出現が明らかに喼められる。このように該部に扔い ては第 2 象牙質の形成状況によって, 不整裂線の有無が 見られるが，てのことについて検討を加えてみたいと思 う. 先ず, 不整裂線の出現が認められる症例についてみ ると，す心゙て第 2 象牙質の形成が大なる隆起として認め ら机る。すすなわ图8のAに見られるように第2 象牙質 之原生象牙質の境界線が象牙質表層部に向って著明な彎 曲をなしている。乙の境界部の原生象牙質に扔ける基質 繊維はその彎曲に沿って配列し，裂隙もまたてれに一致 した彎曲を示して生じている。このような個々の裂隙が 該部に打ける不整裂線として観察されるあのであろう. しかしこれらの不整裂線の出現状況を注意深く観察する と, 症例によって多少の差異が認められる。すなわち第 2 象牙質に抢いてその隆起の辺縁に直交的な裂線（4） の出現が比較的著明飞認められる症例（図 2 の F, I , 図3のC，D図5のA，B）上隆起の辺縁任平行的な裂 線（4）を多く認める症例（図 2 の, $\mathrm{K}$, 図 4 の D F，図５のC）とを比較すると，前者に扔いて原生象牙 
質深層部に不整裂線（3）の出現がやや著明に認められ る。乙れは該部が石灰化不充分で発青成長の途上にあっ た時期に受ける刺激の性状に起因するもの上考えられ る。すなわち急性的な刺激を比較的持続して受けること により，第 2 象牙質の形成発育が早急に要求されて大な る隆起を生ずる結果, その班盛な発育力:強い分力之し て当然発育成長の途上にある該部におよび原生象牙質樑 層部之第 2 象牙質との境界線の彎曲を著明ならしめるた めに不整裂線を出現せしめるあの上考える。

一方不整裂線の出現が認められない症例については, 第 2 象牙質の形成手小であるととから歯に加わる刺激が 軽微で, しかも一時的でありあるいはまた急性的な刺激 であってもその初期においては，その発育力の影響屯お よび難く図 8 のBで見ら机るように第 2 象牙質上の境界 部は著明な彎曲を示すに至らず，したがって裂線も直線

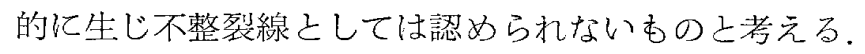

\section{4 第 2 象牙質}

該部においては，中山の見解に基づく防禦反応として の不整裂線の出現が著明に認められる。しかしこれらの 図10
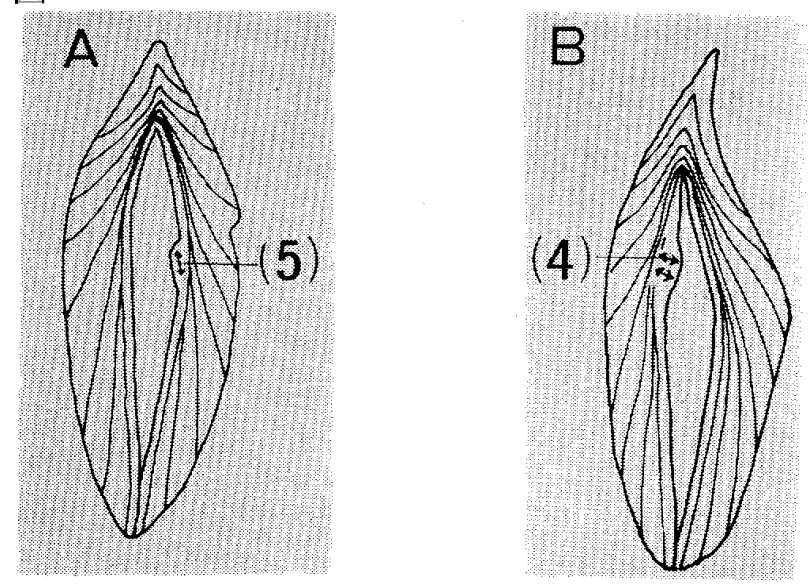

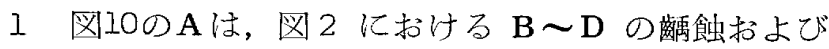
図了に抢けるA，B の磨耗症に見られる症例の模型図で ある。乙崵合，第 2 象牙質の形成活狭少であり，隆起 の辺縁に平行的な1〜2の裂線（5）加認められ，いわ ゆる健康な原生象牙質の䯣腔壁部に执いて見られる裂線 の状況之相促た所見である。これは菌に加わる刺激が比 較的軽微であり，しかも一時的であるため第 2 象牙質の 形成む小で除々に行なわれ，基質繊維の配列状態む図 9 のA，B扔よびCに見るごとく隆起の辺縁に直交的な走 行をなさずDに見られるような辺縁に沿った配列状態を なし象牙質固有の発育状態に類似する層板構造をなすた め単純な裂線として出現するすの上考えられる。
不整裂線の出現状況には，症例によってかなり異なった 所見が認められる。すなわち図 $20 \mathrm{E} ， \mathrm{~F}$ などに見るご 上く第 2 象牙質隆起の辺縁化直交的な裂線（4）のみが 認められる症例，図 2 の〜Dなどに見るごとく隆起の 辺縁に平行的な裂線 (5) のみが】〜2 出現して認めら れる症例, 図 2 の〜 I などに見るごとく隆起の辺縁に 直交的な裂線（4）が出現し，その内側部すなわち䯣胼 側に隆起の辺緣に平行的な裂線（5）が同時に認められ る症例, また図 2 の, Kに兒るごとく第 2 象牙質隆起 の辺縁に平行的な裂線（5）が卫〜2連の弧状線孫化の 傾向を示して認められる症例などである。このように裂 線が異なった所見を呈することは，第 2 象牙質の発育形 成老うながす原因が単一なものでないととから当然それ ぞれ異なった発青様相をなすあのであろうと考えられる が, 裂線の示す方向が当該組織の発育方向を示すすので あると解すれば，防禦反応之して形成された第 2 象牙質 の発育構築を分裂線の上からも把握することが出来るむ の上考える。

この観点にたって不整裂線の出現状況にしたがい図10 の模型図により検討を行なってみたい.
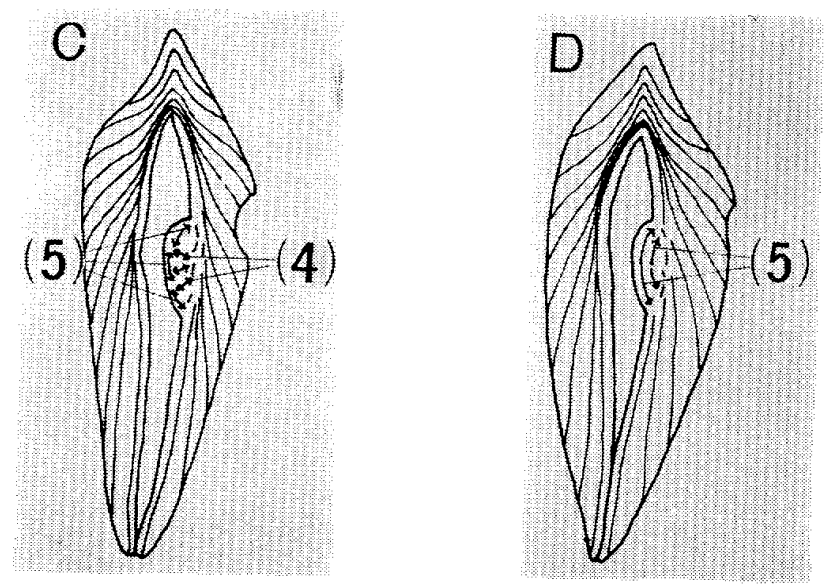

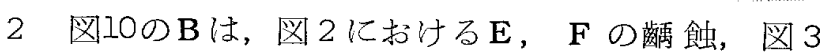
に扔ける C(唇側)，D の磨耗症などに見られる模型図 である．第 2 象牙質の形成が比較的大なる隆起として認 められ，裂線（4）は隆起の辺縁に向って直交的に出現 し限局して認められる。乙れは比較的急性な刺激が持続 的にしかむ広範囲に抢よぶことにより，象牙芽細胞には この刺激に対して防禦反応として急速に第 2 象牙質の形 成が要求され，䨓に加えられる刺激の緩解をなすもの上 考えられる。このような裂線の状況を示す組織像は図 9 のA およびCで見るごよく象牙細管の走行之基質繊維の 主配列方向が上もに第 2 象牙質隆起の辺縁に直交的であ り，裂線もまたその方向に生じている。 


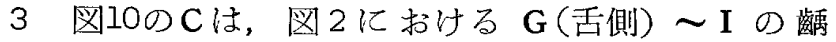
蝕, 図 3 に打けるEの磨耗症扔よび図 5 に打けるBの充 填処置歯などに見ら机る症例の模型図である，第2 象牙 質の形成もさらに増大して認められ，裂線の一群（4） は第 2 象牙質隆起の辺縁任直交的に出現し，その内側部 すなわち䯣腔側部に隆起の辺縁に平行的に出現する一群 の裂線（5）が認められる。乙れは急性期の刺激が急速 に形成された第 2 象牙質によって一応緩解され，その後 続いて加わる慢性的な刺激に対して第 2 象牙質が除々に 形成されたものと考えられる。すなわち歯質の崩壊をと 屯なう急激な刺激に対しててれを緩解するのに最む有効 的な生体防禦反応は，早急な歯質の形成修覆であろうと 考えられる，急造される第 2 象牙質の発育力向は, 刺激 の伝達方向に対して直交的上りむしろ同一方向に形成さ れているととが分裂線の所見から筧える。したがって第 2 象牙質隆起の辺縁に直交的に出現する裂線は不整裂線 の中でも最む緊急的要請にこたえた構築状態を示す裂線 であると考えられる。その内側部すなわち髄控側部に出 現する隆起の辺縁に平行的な裂線（5）は急激な刺激が 一応緩解されたのち加わる軽微な刺激に対して, 緩慢な 防禦反応として形成された第 2 象牙質の構築状態を示す 裂線であると考える.またこれとは逆に軽微な刺激の後 に急激な刺激が加わることにより，隆起の辺縁に平行的 な裂線の内側部すなわち䯣腔側にさらに直交的な裂線が 出現する場合の見られることは当然あり得るととと考え られるでのある。この状況が見られる症例は充填処置が なされた歯の例で，2次䠛蝕の発生が認められた図 50 Aにおいて1例ではあるが認められる。

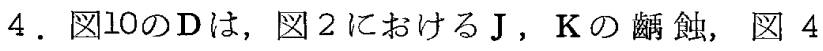

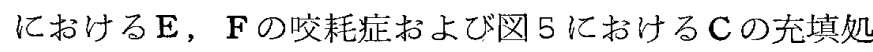
置䨑なぞに見られる症例の模型図である。第 2 象牙質の 形成が大なる隆起として認められ，隆起の辺縁に平行的 な裂線（5）法弧状線系化を示す傾向として認められ る。乙れは比較的長期間にわたる慢性的刺激に対して防 禦反応として形成された第 2 象牙質に招ける構築状態を 示す裂線であると考えられる。

また各症例における分裂線の所見を比較してみると， 䠛蝕, 磨耗症, 咬耗症および充填処置歯などの間にそれ ぞれ特有の分裂線像は認められないが，強いて言えば咬 耗症の菌に打ける裂線の所見に, 第 2 象牙質隆起の辺縁 に平行的な裂線が多く出現し, 辺縁に直交的な裂線は比 較的少ないととである. 特に図 $40 \mathrm{D} \sim \mathrm{F}$ に見る上顎大 歯における分裂線像は, 瞒蝕の慢性的経過を取ったと思 われる症例図 2 の $\mathrm{J} ＼textrm{K} に$ 見られる所見と良く似た状況
を呈し，隆起の辺縁に平行的な裂線が弧状線系化を示す 傾向亡して認められる。乙れは咬耗自体が加令的変化に

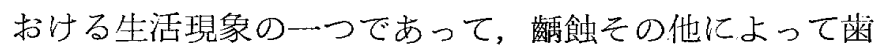
に加えられる刺激などとその発現状況に多少の差異があ るとしても刺激そのあのは慢性的你用するものであ る。したがって分裂線む当然てれ之良く似た所見を呈す るものである。

\section{$\mathrm{V}$ 結 論}

人菌の菼鬲蝕，磨耗症，咬耗症，充填蒾などの象牙質に 招ける分裂線について，中山の見解に基づき防禦反応と しての不整裂線の出現状況に主眼を㧊いて観察し, 次の ごとき結論を得た。

I 各症例において分裂線像には特に差異は認められ ないが，咬耗症に打いて第 2 象牙質の隆起の辺縁に平行 的な不整裂線が直交的な裂線よりも多く出現する傾向が 見られる。

2 原生象牙質表層部には表面および断面ともに不整 裂線の出現は認められない，深層部では不整裂線が認め られる場合と認められない場合とが観察された。これは 第 2 象牙質の発育成長の程度によって，原生象牙質深層 部之第 2 象牙質之の境界線が著明な彎曲をなすか否かに よるあのである。

3第 2 象牙質に扔いてはその隆起の辺縁に直交的な 裂線之，平行的な裂線とが区別された。直交的な裂線は 急性的刺激に対する緊急的な防禦反応として形成された 第 2 象牙質の構築を示すものであると考えられる。平行 的な裂線は，慢性的刺激乙対する緩慢な防禦反応として 形成された第 2 象牙質の構築を示すすのであると考えら れる。

人歯に扣いて屯第 2 象牙質打よび原生象牙質の一部に 明らかに不整裂線の出現が認められ，之の分裂線の状況 加ら当該歯の受ける刺激の性状とそれに対応する第 2 象 牙質の発青梯相を推察し得るものと考える。

稿を終るに当り，終始想篤な御指導と御校閲の労を踢 った，恩師中山種秋教授に対し深甚なる謝意を表しま す。また御援動を頂いた山田博教授ならびに大森忠雄請 師に感謝いたします。

$$
\text { VI 文献 }
$$

1. Georg Bessler; Über dem funktionellen Bau des Knochenkallus. Beiträge zur Anatomie Funktioneller Systeme 440-44l, (1933).

2. G. Mauer ; Untersuchngen über funktionelle Anpassung der Wirbelsäule bei Skoliose. Beiträge zur Anatomie Funktioneller Systeme. 412, 
420, (1933).

3. Max Brodersen; Altersveränderungen am Zahnbein. 1. Die Umschichtung der Zahnbeinlamellen und Umbauten am Tuberculum dentale: Beiträge zur Anatomie Funktioneller Systeme, 133, 134, 143, (1933).

4. 中山種秋; 骨分裂線特に不整裂線の意義：九州歯会 誌, 11(1), 1-14, (1957).

5. 三枝 博; Spaltmethode 亿依りて現れたる象牙質 面の裂向所見：九歯学報，2(2)，1-7，(1938).

6. 山本博武; 人歯牙の分裂線に関する研究 I 象牙質 表面の分裂線について。 II象牙質の縦断面に打ける 分裂線：鹿児島医学誌，34(4)，21-35，(1961).

7. 坂口幸介; 骨緻密質の構築に就て：医学研究，9 (3), 1-78, (1935).

8. 小山次雄; 大腿骨々折の治瘾機転に伴う分裂線の変 化に関する実験的研究，1 Küntscher 氏䯣内固定に 於ける場合の変化：熊本医学会誌, 30 (4), 10531060, (1956).

9. 小山次雄; 大腿骨々折の治瘾機転に伴う分裂線の変 化に関する実験的研究．II変形治癒骨折に於ける場 合の変化：熊本医学会誌，30 (4), 1060-1063, (1956).

10. 佐藤信正; 犬下顎骨の発育に伴う分裂線の变化に就 て: 九州歯会誌1, 2 (2), 57-64, (1958).

11. 内田波夫; 犬下顎骨分裂線の歯科補経に上る变化に 関する実験的研究: 熊本医学会誌. 32(11), 1927一 1942, (1958).

12. 大森忠雄; 犬椎骨の発育に伴う分裂線の変化に就 い: 九州歯会誌, II(5), 20-38, (1958).

13. 森優; 脛骨及び腓骨の骨折治痛部に㧍ける教裂 線について : 医学研究，24 (11)，2261-2262, (1954).

14. 山根博成; 橈骨及び尺骨の骨折治癒部にお甜る罅裂 線について: 久留米医学誌，19(7)，1128-1130, (1956).

15. 阿部 薫; 犬眼球強膜の発育に伴う分裂線の変化に 就いて：熊本医学会誌, 33(4)，268-277，(1959).

16. N. C. TAPPEN; Split-line Patterns in a Series of Skulls of Infant, Juvenile and Adult Gorillas: Am. J. phys, Anthrop, 21 (2), 135-151, (1963).

17. H. Sicher ; Orban's Oral histology and embryology, 112-116, (1966).
18. 一条 尚; 人の歯の基質線維について I 象牙質に 抢ける観察：口病誌，25(4)，184-200，(1958).

19. Yury Kutter ; Classification of dentine into primary, secondary, and tertiary: Oral medicine and Oral pathology, 12, 996, (1959).

20. 加藤 昭; 二次象牙質に関する綜説: 医学研究， 22 (1), 46-53, (1962).

21. 山㥓長夫; 歯根透明象牙質の組織学的並物理学的研 究：口病誌，26(1)，216-231，(1959).

22. 浪江幸太郎; 第 2 象牙質形成阔する病理組織学的 研劣，I 各種条件が第 2 象牙質の組織像に及ぼす影 響について: 函学, 47(2), 3-23, (1959).

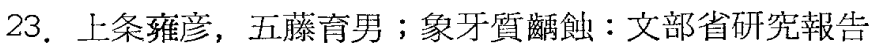
集録・医学及薬学，4，28-429，(1965).

24. 中村博亘; 実験的纪形成された第 2 象牙質の病理組 織学的ならびに組織化学的研究: 歯学, 54(2), 99103, (1966).

25. 粟沢靖之, 内田波夫, 粟沢綮; 象牙質の銀好性原線 維の出現に関する実験的研究: 日組録 4(4) 464468, (1953).

26. 金井昌邦, 田宮由俊, 金光透明, 鹿野善考, 丸山嘉 彦, 高井宏; 象牙質透明層の研究 : 日本憐科医師会 誌, 7(6), 252-253, (1954).

27. Ikuo Goto ; Microradiographic studies on Dental hard tissues-Caries in the Dentin : Bull Tokyo Dent. Coll., 6(3), 114-118, (1965).

28. 岡田正弘, 三村二; 種々薬物の蒾牙象牙質成長及骨 組織形成に及涩す影響に関する醋酸鉛生体染色法に 上る研究: 総合研究班研究報告集・医学及薬学資 料, 22, 310, (1951).

29. 鈴木賢策; Iontophoress K関する実験的研究（特 に根管治療に関連して)：口病誌，16 (6)，1-19, (1942).

30. 桐野忠大; 歯牙組織の染色法 Iontophoress による 銀染色法, 歯科口腔外科最 近の進歩 I , 64-65, 医 蒾薬, (1956).

3I. J. R. PERDRAU; The silver reduction method for the demonstration of connective-tissue fibres: J. Path. and Bacteriol., 24, 117, (1920).

32. Shigeru Matsuno; An improved method for silver impregnation of the argyrophile fiber : Acta Medica Univ. Kagoshima, 3, 27-29, (1960).

33. 佐野 豊; 組織学研究法一理論上術式, 280-286, 南山堂, (1968). 